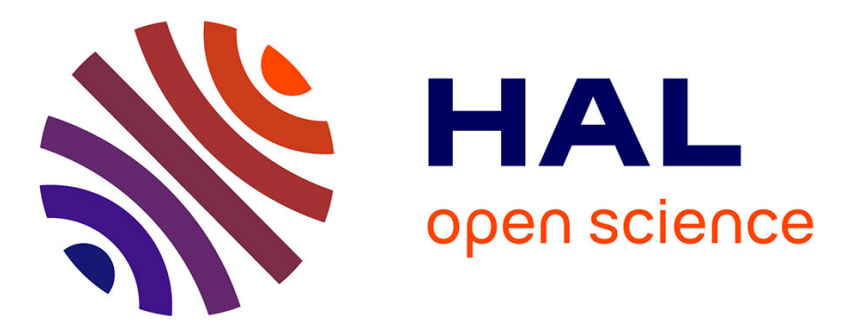

\title{
Discussion on paper entitled "Migration behaviour, of landfill leachate contaminants through alternative composite liners" by G. Varank, A. Demir, E. Sekman, A. Akkaya, K. Yetilezsoy, M.S. Bilgili. \\ N. Touze Foltz
}

\section{To cite this version:}

N. Touze Foltz. Discussion on paper entitled "Migration behaviour, of landfill leachate contaminants through alternative composite liners" by G. Varank, A. Demir, E. Sekman, A. Akkaya, K. Yetilezsoy, M.S. Bilgili.. Science of the Total Environment, 2013, 450-451, pp.372-373. 10.1016/j.scitotenv.2012.01.059 . hal-01084575

\section{HAL Id: hal-01084575 \\ https://hal.science/hal-01084575}

Submitted on 19 Nov 2014

HAL is a multi-disciplinary open access archive for the deposit and dissemination of scientific research documents, whether they are published or not. The documents may come from teaching and research institutions in France or abroad, or from public or private research centers.
L'archive ouverte pluridisciplinaire HAL, est destinée au dépôt et à la diffusion de documents scientifiques de niveau recherche, publiés ou non, émanant des établissements d'enseignement et de recherche français ou étrangers, des laboratoires publics ou privés. 


\title{
Discussion on paper entitled "Migration behaviour, of landfill leachate contaminants through alternative composite liners" by G. Varank, A. Demir, E. Sekman, A. Akkaya, K. Yetilezsoy, M.S. Bilgili.
}

\author{
Nathalie Touze-Foltz \\ Irstea \\ Hydrosystems and Bioprocesses research Unit \\ 1 , rue Pierre-Gilles de Gennes \\ CS 1003092761 Antony cedex \\ France \\ Tel: +33140966039 \\ Fax: +33140966270 \\ E-mail: nathalie.touze@irstea.fr
}

Keywords: composite liners, advective transfers, geomembranes, diffusion

The paper entitled "Migration behaviour, of landfill leachate contaminants through alternative composite liners" by G. Varank, A. Demir, E. Sekman, A. Akkaya, K. Yetilezsoy, M.S. Bilgili is very interesting as it provides information regarding the transfer of various phenolic compounds of interest, and brings to the scientific community data in a field where very few, if no references at all exist. However some technical flaws in the paper could lead to wrong interpretations by readers.

The authors studied four different liner systems among which three include a geomembrane on top of a mineral liner. It is important to notice first that the four reactors R1 to R4 are only properly defined in the abstract of the paper and not in any other location through the paper which makes it difficult for the reader to understand what the four reactors are. 
One can be surprised that metals like copper and zinc cross the geomembrane of reactors R2 to R4 (see Figure 2). Indeed it is well know that cationic and anionic species do not diffuse through geomembranes (Rowe et al., 1995; Rowe, 2011). This means that the geomembranes of reactors $\mathrm{R} 2$ to $\mathrm{R} 4$ exhibit hole(s). No mention of this important point in made through the paper, leading to the potential interpretation by the readers that metals can diffuse through HDPE geomembranes which is erroneous. Metals can only cross geomembrane by advection.

I could get confirmation by the authors during the review process of a "companion paper" (WM_18_868 accepted for publication in Waste Management) entitled "Estimation of transport parameters of phenolic compounds and inorganic contaminants through composite landfill liners using one-dimensional mass transport model", that the geomembranes from reactors R2 to R4 exhibit hole(s). The authors did not however clarify the number of holes drilled in each geomembrane specimen, but a reasonable minimum is one hole. The hole size given by the authors during the review process was equal to $10^{-4} \mathrm{~m}^{2}$.

Assuming a single $10^{-4} \mathrm{~m}^{2}$ hole in the geomembrane, the authors should have calculated the radius of the corresponding wetted area. The wetted area is the area on which a flow will occur between the geomembrane and the underlying mineral liner, in a space called interface. This phenomenon has been evidenced experimentally by various authors (Brown et al., 1987; Touze-Foltz, 2002; Barroso et al, 2006).

Had the authors performed the calculation of the radius of the wetted area assuming good contact conditions for the sake of consistency with the fact that they performed the experiment in the laboratory (flat surface of the soil, no wrinkles in the geomembrane), the 
result obtained would have been as follows using Equation 1 previously proposed by Giroud and Bonaparte (1989) assuming a hydraulic gradient equal to 1:

$\mathrm{R}=\sqrt{\frac{\mathrm{C}_{\mathrm{f}}}{\pi}} \mathrm{a}^{0.05} \mathrm{~h}_{\mathrm{w}}{ }^{0.45} \mathrm{k}^{-0.13}$

Where: $\mathrm{R}$ is the radius of the wetted area $(\mathrm{m}), \mathrm{C}_{\mathrm{f}}$ a contract factor depending on contact conditions, $\mathrm{h}_{\mathrm{w}}$ the hydraulic head (m), and $\mathrm{k}$ the soil liner hydraulic conductivity.

The value of $\mathrm{R}$ obtained assuming a hydraulic head equal to $0.3 \mathrm{~m}$, a hole diameter as given in the paper $\left(10^{-4} \mathrm{~m}^{2}\right)$ and a soil liner hydraulic conductivity equal to $10^{-8} \mathrm{~m} / \mathrm{s}$ with the contact factor $\mathrm{C}_{\mathrm{f}}$ equal to 0.21 (good contact conditions as defined by Giroud and Bonaparte, 1989) is $1 \mathrm{~m}$. In case the hydraulic head considered is only $0.1 \mathrm{~m}$ then the radius of the wetted area is $0.65 \mathrm{~m}$.

This means that with only a single hole in the geomembrane, the liquid flowing through this hole assuming good contact conditions has the ability to flow in the whole interface and to wet the whole area of the mineral liner, as the radius of the reactors is only $0.2 \mathrm{~m}$. Things are just as if there was no geomembrane at all in this particular case, which is not representative of field conditions. The authors should have clearly stated this point in the paper.

The title of the paper is thus in this case erroneous and inappropriate as the authors did not compare the behaviour of composite liners but of mineral liners as the geomembrane is of no use from a hydraulic point of view due to the presence of this hole(s): there were some edge effects in all reactors including a geomembrane specimen. 
It is well know for years (Giroud and Bonaparte, 1989; Bonaparte and Gross, 1993; Rowe, 1998, Bonaparte et al., 2002) that composite liners perform significantly better than single mineral liners, this being again recently evidenced by Pr. Kerry Rowe (Rowe, 2011). The small scale of the tests performed by the authors leads to different results due to the presence of a hole(s) in the geomembrane and the small size of the reactors. It is important that the readers can understand this huge limitation of the study.

Conclusions obtained cannot at all be extended to field cases as the experiments were not performed in conditions representative of in situ conditions.

The only comparison that the authors can give here is for the mineral liners as everything is as if there was no geomembrane present in the system.

What the authors studied, despite the presence of a geomembrane is advective-diffusive transfers through mineral liners.

Very different results would have been obtained at a larger scale and/or without a hole in the geomembrane. Conclusions should have been restricted to the scale tests and no attempt made to give conclusions for in situ conditions as they can lead to the interpretation that composite liners do not perform significantly better than single mineral liners, which is totally erroneous and could lead to unfortunate regressions as far as the design of liner systems for landfills is concerned.

\section{References}

Bonaparte, R, Daniel, DE, Koerner, RM. Assesment an recommendations for improving the performance of waste containment systems, EPA report CR-821448-01-0; 2002. 
Bonaparte, R, Gross, BA. LDCRS flow from double-lined landfills and surface impoundments, EPA, Cincinatti, 65 p; 1993.

Brown, KW, Thomas, JC, Lytton, RL, Jayawickrama, P, Bhart, S. Quantification of leakage rates through holes in landfill liners. US EPA Report CR810940; 1987.

Rowe, RK, Hrapovic, L, Kosaric, N. Diffusion of chloride and dichloromethane through an HDPE geomembrane HDPE geomembrane. Geosynthetics International, 1995; 2(3): 507-536.

Rowe, R.K. (2012). Short- and long-term leakage through composite liners. The 7th Arthur Casagrande Lecture Canadian Geotechnical Journal 2012 49(2): 141-169.

Touze-Foltz, N. The influence of non-uniform transmissivity vis-à-vis hole location. Geotextiles and Geomembranes, 2002; 20(4): 263-277.

Giroud, JP, Bonaparte, R. Leakage through liners constructed with geomembranes. Part II Composite liners. Geotextiles and Geomembranes, 1989; 8(2): 71-111.

Barroso, M, Touze-Foltz, N, von Maubeuge, K, Pierson, P. Laboratory investigation of flow rate through composite liners consisting of a geomembrane, a GCL and a soil liner. Geotextiles and Geomembranes, 2006; 24(3): 139-155. 